\title{
Analysis of growth and quality of seaweed carrageenan Kappaphycus alvarezii in different locations on the Banggai's Waters, Central Sulawesi
}

\section{Analisis pertumbuhan dan kualitas karagenan rumput laut Kappaphycus alvarezii pada lokasi berbeda di Wilayah Perairan Banggai Provinsi Sulawesi Tengah}

\author{
Frederik Dony Sangkia ${ }^{1}$, Grevo S. Gerung ${ }^{2}$, dan Roike I. Montolalu ${ }^{2}$ \\ ${ }^{1}$ Program Studi Ilmu Perairan, Program Pascasarjana Universitas Sam Ratulangi. Jln. Kampus Unsrat Kleak, \\ Manado 95115, Sulawesi Utara, Indonesia. \\ ${ }^{2}$ Fakultas Perikanan dan Ilmu Kelautan, Universitas Sam Ratulangi. Jl. Kampus Unsrat Bahu, Manado 95115, \\ Sulawesi Utara, Indonesia. \\ *E-mail: dony.sangkia@gmail.com
}

\begin{abstract}
Seaweed is a potential of coastal resources. Carrageenan is a polysaccharide extracted from seaweed or some species of red algae (Rhodophyceae). Seaweed growth is strongly influenced by two factors: internal and external factors. But twthat determine the success of the seaweed growth is the management carried out by people working on it. Banggai Regency is one of the largest seaweed production centers in Central Sulawesi. The main objective of this study is to examine the potential of seaweed cultivation (Kappaphycus avarezii) by looking at the growth and the carrageenan, in Banggai waters, Central Sulawesi Province. The temperature range obtained during this study $\mathrm{r} 25$ to $31^{\circ} \mathrm{C}$. The results of carrageenan analiysis was very different due to differences in location, showed by content. The highest and lowest ash content were obtained from two locations, $1,8 \%$ (Jayabakti) and 2.8\% (Liang), respectively.
\end{abstract}

Keywords: carrageenan; seaweed; Kappaphycus alvarezii; Banggai; Central Sulawesi.

Abstrak: Rumput laut merupakan sumberdaya pesisir yang sangat potensial. Karagenan merupakan polisakarida yang diekstraksi dari beberapa spesies rumput laut atau alga merah (rhodophyceae). Pertumbuhan rumput laut sangat dipengaruhi oleh dua faktor yaitu faktor internal dan faktor eksternal. Namun yang sangat menentukan keberhasilan pertumbuhan rumput laut yaitu pengelolaan yang dilakukan oleh manusia. Kabupaten Banggai merupakan salah satu sentral produksi rumput laut terbesar di Sulawesi Tengah. Tujuan utama penelitian ini mengkaji tentang potensi budidaya rumput laut (Kappaphycus alvarezii) yang dikembangkan dengan melihat pertumbuhan dan analisis karaginannya di perairan Kabupaten Banggai Provinsi Sulawesi Tengah. Kisaran suhu yang didapat selama penelitian ini adalah berkisar $25-31^{\circ} \mathrm{C}$. Hasil analisa rendemen karagenan ini sangat berbeda yang disebabkan oleh perbedaan lokasi memberikan pengaruh nyata terhadap kandungannya. Nilai kadar abu tertinggi dan terendah berturut-turut yang di peroleh dari kedua lokasi ini adalah 1,8\% (Jaya Bakti) dan 2,8\% (Liang).

Kata-kata kunci: karagenan; rumput laut; Kappaphycus alvarezii; Banggai; Sulawesi Tengah.

\section{PENDAHULUAN}

Rumput laut merupakan sumber daya pesisir, sumber pendapatan nelayan, dapat menyerap tenaga kerja, dan mampu memanfaatkan lahan perairan pantai. Indonesia sebagai negara kepulauan, sangat potensial dalam pengembangan rumput laut (Aslan, 2005). Indonesia menargetkan produksi rumput laut pada tahun 2011 sebanyak 3 juta ton rumput laut kering, untuk memenuhi permintaan pasar dunia (Ma'ruf, 2010).
Menurut Sulaeman et al. (2005), pertumbuhan rumput laut sangat dipengaruhi oleh dua faktor, yaitu faktor internal (seperti jenis, galur, bagian thallus, dan umur) dan faktor eksternal (seperti keadaan fisik dan kimiawi perairan). Namun demikian, selain faktor-faktor tersebut, ada faktor lain yang sangat menentukan keberhasilan pertumbuhan dari rumput laut, yaitu pengelolaan yang dilakukan oleh manusia. Menurut Puslitbangkan (1991) dan Soegiarto and Sulistijo (1978), laju pertumbuhan rumput laut 
yang dianggap cukup menguntungkan adalah di atas $3 \%$ pertambahan berat perhari.

Karagenan adalah polisakarida yang diekstraksi dari beberapa spesies rumput laut atau alga merah (Rhodophyceae), misalnya karagenan iota, kappa, dan lambda, yang diperoleh dari spesies Rhodophyta yang berbeda. Karagenan komersial memiliki berat molekul massa rerata berkisar 400.000 sampai 600.000 Da (van De Velde et al., 2002). Sehubungan dengan hal tersebut maka perlu dilakukan penelitian untuk mengetahui pertumbuhan dan kandungan karaginan.

Kabupaten Banggai merupakan salah satu sentral produksi rumput laut terbesar di Sulawesi Tengah, karena tingkat ketersediaan lahan pengolahan rumput laut di Banggai Kepulauan (Bangkep) mencapai 12.031 ha; dari jumlah itu pemanfaatan baru mencapai 4.425,26 ha, dengan capaian produksi pada tahun 2009 sebesar 127.536 ton rumput laut kering. Bangkep menyumbang sekitar $26,57 \%$ dari total produksi rumput laut Sulawesi Tengah, yang mencapai 480.000 ton. Menurut data yang ada pada Asosiasi Rumput Laut Indonesia (ASRINDO), Kabupaten Banggai, pada tahun 2009, memproduksi rumput laut sebesar 10.628 ton lebih/bulan atau 127.536 ton/tahun. Di Kecamatan Liang, dengan jumlah penduduknya 8.608 jiwa, pada tahun 2008, 1.818 jiwa $(21,11 \%)$ penduduknya menggantungkan hidupnya sebagai petani rumput laut. Jenis rumput laut yang dibudidayakan di kecamatan ini adalah spesies Kappaphycus alvarezii, dengan metode pembudidaya rumput laut dengan tali bentangan apung (floating long line method).

Tujuan utama penelitian ini adalah mengkaji potensi budidaya rumput laut yang dikembangkan di perairan Kabupaten Banggai, Provinsi Sulawesi Tengah, khususnya melihat pertumbuhan dan menganalisis karaginannya.

Faktor-faktor lingkungan yang mempengaruhi pertumbuhan rumput laut, antara lain, yaitu suhu (Sulistijo, 1994; Eidman, 1991), kecepatan arus (Sulistijo, 1994), salinitas (Anggadireja, et al., 2006; Mutmainna, 2005), kecerahan (Mutmainna, 2005) dan pH (Aslan, 2005; Poncomulyo et al., 2006).

\section{MATERIAL DAN METODA}

Penelitian ini dilakukan di dua lokasi perairan Provinsi Sulawesi Tengah, yaitu di perairan Desa Liang, Kecamatan Liang, Kabupaten
Banggai Kepulauan, dan Desa Jayabakti, Kecamatan Pagimana, Kabupaten Banggai.

Rancangan penelitian yang digunakan adalah Rancangan Acak Kelompok (RAK) dengan tiga ulangan. Prosedur penelitian yang dilakukan dimulai dari tahap persiapan, tahap pengambilan organisme rumput laut dari lokasi, dan tahap pengukuran kualitas air. Kualitas rumput laut berupa rendemen karegenan, kadar air, dan kadar abu dianalisis di Laboratorium Farmasi, Fakultas MIPA, dan Laboratorium Pengendalian Mutu Hasil Perikanan, Fakultas Perikanan dan Ilmu kelautan, Universitas Sam Ratulangi. Untuk mengetahui rendemen karaginan di setiap lokasi, maka sampel dianalisa di Laboratorium Produktivitas dan Kualitas Perairan, Fakultas Ilmu Kelautan dan Perikanan, Universitas Hasanuddin, Makassar. Peubah yang diamati meliputi laju pertumbuhan spesifik harian, salinitas, suhu, arus, kecerahan dan kedalaman.

Untuk mengukur laju pertumbuhan spesifik harian rumput laut, maka digunakan rumus (Dawes et al., 1986):

$$
\mathrm{SGR}=\frac{\mathrm{LnWt}-\mathrm{LnWo}}{\mathrm{t}} \times 100 \%
$$

di mana:

SGR = Laju pertumbuhan spesifik (\%)

$\mathrm{Wt}=$ Bobot rumput laut pada waktu $\mathrm{t}(\mathrm{g})$

Wo = Bobot rata-rata bibit pada waktu awal

(g)

$\mathrm{t}=$ Periode pengamatan (hari)

Untuk mengetahui karakteristik karaginan, maka dilakukan dengan menguji rendemen, kadar air dan kadar abu.

\section{Rendemen karaginan (SNI M03-70-1990)}

Rendemen karaginan (SNI M03-70-1990) sebagai hasil ekstraksi dihitung berdasarkan rasio antara berat keraginan yang sudah dipanaskan dikurangi dengan berat cawan kosong dengan berat sampel kering yang digunakan.

\section{Kadar air}

Pengujian kadar air menggunakan panduan dari Sudarmaji et al. (1989), sebagai berikut:

1. Terlebih dahulu cawan porselen dikeringkan selama 1 jam dalam oven pada suhu $105^{\circ} \mathrm{C}$, kemudian didinginkan dalam desikator selama 15 menit dan timbang (x).

2. Sampel ditimbang dengan teliti sebanyak 1 gr (y) dan di masukkan dalam cawan porselen. 
3. kemudian cawan porselen dan sampel yang berada di dalamnya dimasukkan ke dalam oven pada suhu $105^{\circ} \mathrm{C}$ untuk dikeringkan selama 8 jam.

4. Kemudian didinginkan dalam desikator selama 30 menit, lalu ditimbang beratnya (z).

Rumus:

$$
\begin{aligned}
& \text { Kadar BK }=\frac{\mathrm{z}-\mathrm{x}}{\mathrm{y}} \times 100 \% ; \\
& \text { Kadar air }=100 \%-\mathrm{BK}
\end{aligned}
$$

\section{Kadar Abu}

Pengujian kadar abu menggunakan panduan dari AOAC (1995), sebagai berikut:

1. Cawan porselen dikeringkan terlebih dahulu selama 1 jam dalam oven pada suhu $105^{\circ} \mathrm{C}$, kemudian didinginkan dalam desikator selama 15 menit dan ditimbang (a).

2 Sampel ditimbang dengan teliti sebanyak 1 gr (b), dan dimasukkan ke dalam cawan porselen.

3. Kemudian cawan bersama sampel yang berada di dalamnya di masukkan dalam tanur dengan suhu $600^{\circ} \mathrm{C}$ kemudian dibiarkan selama 3 jam sampai sempurna menjadi abu.

4. Sampel dibiarkan sampai dingin kemudian dimasukkan ke dalam desikator selama $1 / 2$ jam.

5. Kemudian sampel di timbang (c).

Rumus: Kadar $\mathrm{abu}=\frac{\mathrm{c}-\mathrm{a}}{\mathrm{b}} \times 100 \%$

\section{Kualitas Air}

Data kualitas air meliputi pengukuran suhu, salinitas, kecepatan arus dan kecerahan. Pengukuran salinitas dan suhu dilakukan setiap 15 hari, pada siang hari.

\section{Analisa Data}

Untuk mengetahui perbedaan antara perlakuan digunakan Analisis Ragam (ANOVA) dengan menggunakan Program SPSS ${ }^{\circledR}$ versi 19 (Statistical Package for Social Sciences). Bila

Tabel 1. Parameter Kualitas Air di lokasi penelitian

\begin{tabular}{ccccc}
\hline No. & Parameter & Satuan & $\begin{array}{c}\text { Desa } \\
\text { Liang }\end{array}$ & $\begin{array}{c}\text { Desa } \\
\text { Jayabakti }\end{array}$ \\
\hline 1. & Suhu & ${ }^{\circ} \mathrm{C}$ & $25-26$ & $29-31$ \\
2. & Kecerahan & ${ }^{\circ}$ o & 100 & 100 \\
3. & Arus & $\mathrm{cm} /$ detik & $12-48$ & $12-48$ \\
4. & Kedalaman & $\mathrm{Cm}$ & $500-700$ & $500-600$ \\
& perairan & & & \\
5. & Salinitas & $\mathrm{ppt}$ & $30-33$ & $30-31$ \\
6. & $\mathrm{pH}$ & - & $7-8$ & $7-8$ \\
\hline
\end{tabular}

terjadi perbedaan di antara perlakuan dilanjutkan dengan uji BNT atau LSD (Gaspersz, 1994).

\section{HASIL DAN PEMBAHASAN}

\section{Kondisi Lingkungan Perairan}

Rumput laut dalam kehidupannya tidak terlepas dari pengaruh faktor dari dalam maupun faktor dari luar. Gambaran tentang biofisik air laut penting diketahui karena dapat mempengaruhi perkembangan rumput laut. Faktor luar yang mempengaruhi perkembangan rumput laut, antara lain, adalah faktor fisika, kimia dan biologi perairan. Hasil pengukuran dan pemantauan parameter kualitas air di lokasi budidaya di desa Liang dan desa Jayabakti selama penelitian dan parameter ideal dirincikan pada Tabel 1 .

Tabel 1 menunjukkan hasil yang berada dalam batas kisaran yang normal untuk budidaya rumput laut. Parameter kualitas air yang normal dapat menunjang proses pertumbuhan rumput laut $K$. alvarezii. Suhu perairan merupakan salah satu faktor yang sangat penting dalam mempelajari gejala-gejala fisika air laut dan perairan yang dapat mempengaruhi kehidupan hewan dan tumbuhan pada perairan tersebut. Suhu perairan mempengaruhi laju fotosintesis. Nilai suhu perairan yang optimal untuk laju fotosintesis berbeda pada setiap jenis.

Suhu perairan sangat mempengaruhi kehidupan biota perairan. Kenaikan suhu yang melebihi batas optimum dapat menekan pertumbuhan bahkan menyebabkan kematian organisme akuatik. Hal ini diakibatkan, selain berpengaruh langsung, suhu juga mempengaruhi pertukaran zat dan kelarutan gas-gas dalam air, termasuk kelarutan oksigen.

Kisaran suhu yang didapat selama penelitian ini adalah berkisar $25-31^{\circ} \mathrm{C}$. Sedangkan menurut Supit (1989), bahwa kisaran temperatur yang baik untuk pertumbuhan rumput laut adalah $21-31^{\circ} \mathrm{C}$. Dengan demikian kisaran suhu perairan selama penelitian cukup baik atau sesuai untuk pertumbuhan rumput laut.

\section{Pertumbuhan}

Pertumbuhan rumput laut jenis $K$. alvarezii pada kedua lokasi penelitian adalah berbeda nyata $(p<0,05)$; artinya perbedaan lokasi budidaya rumput laut antara Liang dan Jayabakti mempengaruhi laju pertumbuhan harian rumput laut. Dikatakan, bahwa pertumbuhan rumput laut yang dibudidayakan pada lokasi perairan yang 
Sangkia et al.: Analysis of growth and quality of seaweed carrageenan Kappaphycus alvarezii ...

Tabel 2. Hasil rendemen karagenan, Kadar Air dan Kadar Abu

\begin{tabular}{lrr}
\hline \multicolumn{1}{c}{ Analisis } & Desa Liang & Desa Jayabakti \\
\hline Rendemen Karagenan (\%) & $35,88 \%$ & $39,61 \%$ \\
Kadar Air (\%) & $9,30 \%$ & $27,00 \%$ \\
Kadar Abu (\%) & $2,80 \%$ & $1,80 \%$ \\
\hline
\end{tabular}

berbeda itu mendapatkan kondisi perairan yang berbeda, baik kondisi fisika dan kimia. Di samping itu, hal lain yang diduga menyebabkan tidak berbedanya pertumbuhan jenis rumput laut tersebut adalah kemampuan menyerap unsurunsur hara atau makanan di perairan adalah hampir sama.

Faktor-faktor fisika dan kimia serta bermacam-macam substrat sangat menentukan terhadap pertumbuhan rumput laut yang diuji. Hasil pengukuran parameter fisika di lokasi penelitian ternyata sangatlah menunjang dan mendukung pertumbuhan rumput laut jenis $K$. alvarezii. Pertumbuhan thalus rumput laut sangat dipengaruhi oleh dua faktor, yaitu faktor internal dan faktor eksternal. Faktor internal yang berpengaruh, antara lain, jenis, galur, talus (bibit), dan umur; sedangkan faktor eksternal yang berpengaruh, antara lain, adalah lingkungan, bobot bibit, jarak tanam, teknik penanaman, dan metode budidaya. Keberhasilan budidaya dipengaruhi oleh metode budidaya yang digunakan. Sebaiknya metode disesuaikan dengan kondisi fisik dan perairan yang digunakan sebagai lahan budidaya (Afrianto dan Liviawaty, 1989).

\section{Kadar Karagenan}

Hasil analisis rendemen karagenan sangat berbeda (Tabel 2); hal ini mungkin disebabkan oleh perbedaan tempat atau iklim dan musim. Dengan kata lain, bahwa lokasi memberikan pengaruh nyata terhadap kandungan karagenan, yang diduga disebabkan oleh penyerapan unsurunsur hara dan kemampuan menyesuaikan diri yang berbeda-beda terhadap kondisi lingkungan perairan. Supit (1989) menyatakan, bahwa suatu jenis rumput laut pada lokasi yang berbeda akan menghasilkan perbedaan rendemen karagenan.

\section{Kadar Abu}

Analisis kadar abu dilakukan untuk mengetahui secara umum kandungan mineral yang terdapat dalam karaginan. Nilai kadar abu suatu bahan pangan menunjukkan besarnya jumlah mineral yang terkandung dalam bahan pangan tersebut (Afrianto and Liviawaty, 1989). Nilai kadar abu tertinggi dan terendah berturut- turut yang di peroleh dari kedua lokasi ini adalah 1,8\% (Jayabakti) dan 2,8\% (Liang) (Tabel 2).

Rumput laut termasuk bahan pangan yang mengandung mineral cukup tinggi, karena kemampuannya dalam menyerap mineral yang berasal dari lingkungannya. Perairan dengan salinitas yang tinggi menyebabkan rumput laut banyak mengandung garam-garam mineral. Mineral makro seperti $\mathrm{Na}, \mathrm{Ca}, \mathrm{K}, \mathrm{Cl}, \mathrm{Mg}, \mathrm{P}, \mathrm{S}$, dan trace element seperti $\mathrm{I}, \mathrm{Mn}, \mathrm{Cu}, \mathrm{Fe}$ banyak dijumpai pada rumput laut (Afrianto and Liviawaty, 1989).

\section{Kadar Air}

Pengujian kadar air dimaksudkan untuk mengetahui seberapa besar kandungan air dalam karaginan. Kadar air dalam karaginan sangat berpengaruh terhadap daya simpannya. Kandungan air karaginan yang terukur merupakan air terikat terutama yang terikat secara kimia, sedangkan air bebas kemungkinan telah menguap (Tabel 2). Pertambahan umur panen cenderung menyebabkan kadar air karaginan mengalami peningkatan. Hal ini diduga karena sifat hidrofiliknya sehingga rumput laut dapat menyerap air yang cukup banyak ketika semakin lama dalam perairan. Dengan tingginya kadar air pada rumput laut, diduga kandungan air karaginan dalam rumput laut juga meningkat.

\section{KESIMPULAN}

Berdasarkan hasil penelitian, perbedaan lokasi memberikan pengaruh terhadap konsentrasi kandungan karagenan. Rumput laut $K$. alvarezii mempunyai pertumbuhan yang baik di lokasi penelitian. Parameter yang paling berpengaruh terhadap pertumbuhan rumput laut dan konsentrasi karagenan adalah suhu, salinitas, dan kecepatan arus yang tinggi sehingga menghasilkan kualitas karagenan yang baik. 


\section{REFERENSI}

AFRIANTO, E., and LIVIAWATY, E. (1989) Pengawet dan Pengolahan Ikan. Yogyakarta: Penerbit Kanisius. 12 pp.

ANGGADIREJA, J.T., ZATNIKA, A., PURWOTO, H. and ISTINI, S. (2006) Rumput Laut. Pembudidayaan, Pengolahan dan Pemasaran Komoditas Perikanan Potensial. Jakarta: Penebar Swadaya.

AOAC (1995) Official Methods of Analysis of the Association of Official Analitycal Chemist. Inc. Washington DC. pp. 185-189.

ASLAN, L.M. (2005) Budidaya Rumput Laut. Yogyakarta: Penerbit Kanisius.

DAWES, C.J., LUISMA, A.O. and TRONO, G.C. (1986) Laboratory and Field Growth Studies of Commercial Strains of Eucheuma denticulatum and Kappaphycus alvarezii in The Philippines. J. Appl. Phycol., 6, 21-24.

EIDMAN, H.M. (1991) Studi Efektifitas Bibit Algae Laut (Rumput Laut). Salah Satu Upaya Peningkatan Produksi Budidaya Algae Laut (Eucheuma sp.). Laporan Penelitian. Bogor: Fakultas Perikanan, Institut Pertanian Bogor. 74 pp.

GASPERSZ, V. (1994) Metode Perancangan Perco-baan; Untuk Ilmu-Ilmu Pertanian, IlmuIlmu Tekhnik dan Biologi. Bandung: CV. Armico. Hal. 8-13.

MA'RUF, F. (2010) RI Produsen Rumput Laut Terbesar. Informasi Rumput Laut Indonesia. www.kabarbisnis.com.

MUTMAINNA (2005) Petunjuk Teknis Budidaya Rumput Laut. Laporan Tahunan. Balai Budidaya Air Payau Takalar. Departemen Kelautan Dan Perikanan Direktorat Jenderal Perikanan Budidaya.
PONCOMULYO, T., MARYANI, H. and KRISTIANI, L. (2006) Budidaya dan Pengelolaan Rumput Laut. Jakarta: Agro Media.

PUSLITBANGKAN (1991) Budidaya Rumput Laut (Eucheuma sp.) Dengan Rakit dan Lepas Dasar. Jakarta: Pusat Penelitian dan Pengembangan Perikanan, Badan Penelitian Pengembangan Pertanian. 9 pp.

SULAEMAN, A., PARENRENGI, E., SURYATI and TENRIULO, A. (2005) Genetical and morphological differences of two different variety of seaweed Kappaphycus alvarezii. Paper presented at World Aquaculture Society, Denpasar. 5 pp.

SOEGIARTO, A. and SUliSTIJO (1978) Produksi dan Budidaya Rumput Laut. Jakarta: Lembaga Oseanologi Nasional LIPI.

SUDARMADJI, et al. (1989) Analisa Bahan Makanan dan Pertanian. Edisi I. Cetakan Ketujuh. Yogyakarta: Kanisius.

SULISTIJO (1994) Perkembangan Budidaya Rumput Laut di Indonesia. Puslitbang Oseanologi. Jakarta: LIPI.

SUPIT, D.S. (1989) Karakteristik dan kandungan rumput laut Eucheuma cottonii (Doty) yang berwarna abu-abu, coklat dan hijau yang ditanam di coba di lapangan pasir Pulau Pari. Bogor: Institut Pertanian Bogor. p. 15-18.

VAN DE VELDE, F., KNUTSEN, S.H., USOV, A.I., ROMELLA, H.S. and CEREZO, A.S. (2002) $1 \mathrm{H}$ and $13 \mathrm{C}$ High Resolution NMR Spectoscopy of Carrageenans: Aplication in Research and Industry. Trend in Food Science and Technology, 13, 73-92.

Received: 15 January 2018 Accepted: 15 March 2018 